doi: $10.19090 /$ i.2019.30.197-216

PAULINA ČOVIĆ

University of Novi Sad, Faculty of Philosophy

Department of History

covic.paulina@gmail.com

\title{
FOREIGN STUDENTS AT THE UNIVERSITY OF BELGRADE AND THEIR INTEREST IN THE HISTORY OF SOUTH SLAVS (1923-1941)
}

\begin{abstract}
The paper examines the schooling of foreign students, holders of the scholarships awarded by the Ministry of Education of the Kingdom of Serbs, Croats and Slovenes/Yugoslavia, at the University of Belgrade between the two World Wars. The first competitions were opened mid 1920s, with those countries which aided the schooling of Yugoslav students at their respective universities being eligible to apply. During the 1930s student exchange continued, in an apparently more extensive and organized manner, only to be extended at the end of the period under review to include countries with which the Kingdom of Yugoslavia, in accordance with the change of foreign policy orientation, established close political and economic relations. Thus, in the beginning, students from France, Great Britain, Czechoslovakia and Poland came to study in Belgrade, whereas, during the years before World War II, students also came from Turkey, Germany and Italy. Scholarship holders most often worked on developing their knowledge of Serbo-Croatian-Slovenian, studied literature and Yugoslav culture in general. Many of them chose to study history, whether as part of their undergraduate or specialist studies. They are the particular focus of this study. The paper is based on unpublished archival sources, periodicals and relevant historiographic literature.

Keywords: The Kingdom of Serbs, Croats and Slovenes/Yugoslavia, the Ministry of Education, cultural policy, the University of Belgrade, scholarships, foreign students, history.
\end{abstract}

\section{Foreign students at the University of Belgrade during the 1920s}

$\mathrm{T}$ There is a long-standing tradition in Serbia of intellectuals receiving their education abroad. It can be traced back to the beginnings of higher education and somewhat later to World War I, when Serbian students received their education in France and Great Britain. ${ }^{1}$ The schooling of students at foreign universities continued between the two World Wars. An oft-cited piece of information states that $59 \%$ of the university professors

\footnotetext{
Janićijević 1984: 48-53; Dimić 1997: 344, 347; Ostojić-Fejić 1989; Marković 1992: 194-196. The education of the intellectual elite at foreign universities in the $19^{\text {th }}$ century was extensively researched by historian Ljubinka Trgovčević-Mitrović. See also: Grbić 1988.
} 
between the two World Wars graduated and as many as $74 \%$ received their doctorate at a university abroad. ${ }^{2}$ In addition to numerous tasks as part of the state cultural policy, the University of Belgrade was also tasked with decreasing the number of students leaving to foreign institutions of higher education and enrolling foreign students. This meant challenging the dominant view that "a foreign education is a prerequisite of the attainment of knowledge". ${ }^{3}$ According to a survey from 1925, foreigners accounted for $18 \%$ of the total number of students. ${ }^{4}$ Among them, however, the majority were Russian white émigrés, although, for the first time, there was also a small number of foreign students, who were awarded scholarships by the Ministry of Education of the Kingdom of the Serbs, Croats and Slovenes (SCS). Thus, by the 1920s, students from France, Great Britain, Czechoslovakia and Poland arrived to Belgrade..$^{5}$ These first steps towards the establishment of an international university cooperation, not including Great Britain, were in line with the direction of the foreign policy from which, consequently, cultural ties also ensued.

Yugoslav foreign policy between the two World Wars advocated for the preservation of the inviolability of peace treaties and the prevention of revisionist attempts by making defensive alliances and bilateral contracts of friendship and cooperation. As early as 1919 diplomatic relations with France, Czechoslovakia and Poland were established. Over the next period they were strengthened by making political alliances and entering into contracts of economic-trade exchange. ${ }^{6}$ An important place in the overall relations between countries was reserved for cultural introductions and familiarization. ${ }^{7}$ During the first decade of its existence, the Kingdom of SCS was politically and culturally directed towards France. The ties established in the $19^{\text {th }}$ century were strengthened by the alliance from the Great War, which resulted in allied, friendly political relations between the two World Wars. French cultural influence permeated art, literature, science, education, everyday life, reaching wide layers of population. Vibrant cultural ties and frequent contacts were maintained until mid 1930s. Among various forms of cultural cooperation that existed between the two countries,

Marković 1992: 194-196; Id. 1989: 190; Dimić 1997: 347; Janićijević 1984: 109-110.

Dimic 1997: 347, 370. This was important as it reflected the idea that the University of Belgrade was part of the European currents of science and education as its member in good standing. Marković 1989: 191; Tešić 1974: 319; Samardžić 1974: 335.

4 Stanković 2000: 49-50.

5 Archives of Yugoslavia, Belgrade, the Ministry of Education of the Kingdom of Yugoslavia, 66-129-411. (AJ, 66)

6 France, Czechoslovakia and the Kingdom of SCS were directed towards each other with the alliance Little Entente, created as a result of a series of defensive contracts, aimed against the revisionist aspiration of Hungary and Bulgaria: the contract between the Kingdom of SCS and Czechoslovakia (1920), between Romania and Czechoslovakia (1921), and between Romania and the Kingdom of SCS (1921).

Apart from that, the Kingdom of SCS also signed the Contract of the alliance for the preservation of peace and strengthening of political and economic ties with Czechoslovakia in 1922. During the 1920s the Kingdom of SCS and the Republic of Poland signed several bilateral contracts, the most important of which was the Pact of friendship and amenable cooperation form 1926. In 1927 the respective ministers of foreign affairs, Aristide Briand and Vojislav Marinković, signed the friendship contract, which was supposed to be in force for five years, with the possibility of renewal. The Contract was extended in 1932, and renewed in 1937, after the creation of the Rome-Berlin axis. Jovanović 1939: 238, 343, 348, 531-533; Dimitrijević, Sretenović 2008: 50-54; Krizman 1975: 32-36, 44, 152, 156-157, 161-162; Sretenović 2008: 108-111, 195; Vinaver 1985 9-13, 17-22, 31-34, 40-42, 116-128.

7 Dimić 1997: 186, 229-230; Bondžić 2017: 97-98; See also: Sretenović 2009. 
the most frequent was the education students received at French universities and the scholarships awarded to them. ${ }^{8}$ The Kingdom of SCS achieved particularly close cultural ties with Czechoslovakia and Poland, the countries with which, apart from the ethnic and linguistic connections and the tradition of Pan-Slavism instituted during earlier periods, it was also connected by the fact that at the end of the Great War they all established their independent, national countries. In addition to being an important element in the affirmation of the national identity, the culture of these countries was a prerequisite of their integration in the "family of European nations". Pan-Slavic cultural mutuality represented the foundation of the state ideology of all three nations. Cultural ties with these nations were primarily achieved by means of literature, physical culture and educational-pedagogic influences. ${ }^{9}$ Up until the second half of the 1930 s, in line with the weak political ties, there were hardly any cultural contacts with Great Britain. Moreover, very little was done to establish them. The only foothold of the British culture in the Kingdom of Yugoslavia were the anglophile societies. Ties were traditionally kept with the British Support Fund for the education of pupils and students in London. ${ }^{10}$

Since cultural and scientific connections between the Yugoslav Kingdom and the aforementioned countries during the 1920s were sporadic, a continual exchange of scholarships, and by extension the education of foreign students, was meant to contribute to the efforts of their mutual familiarization and fraternization. The cooperation was principally established with those countries which sponsored the education of Yugoslav students at their respective universities. As early as the school year 1923/1924 there were two foreign students enrolled at the Faculty of Philosophy, the University of Belgrade, one from Czechoslovakia, and the other from Great Britain. ${ }^{11}$ It was as early as 1922 that Mihailo Gavrilović, a delegate of the Kingdom of SCS in London, put forth a proposition to establish mutual scholarships as a symbol of gratitude to the British government which funded the education of a number of Yugoslav students. Based on the cooperation established with the school of Slavonic and East European studies in London, the Ministry of Education, beginning with 1923, awarded one scholarship every year to an English student for a two-year study of language and literature at the Faculty of Philosophy in Belgrade. This was considered to be a good way of spreading Yugoslav propaganda in London. ${ }^{12}$ The government of the Republic of Czechoslovakia also wholeheartedly assisted the schooling of Yugoslav students in Czechoslovakia between 1921 and 1923. ${ }^{13}$ Financial aid was set up at the universities and schools of higher education in Prague and Brno for the schooling of students, with meals at cafeterias and lodging in student dorms provided for Yugoslav students. The president of Czechoslovakia Tomáš Masaryk himself donated

Čalić 2013: 135-138; Dimić 1997: 186-204.

Ibid. 229-244; Bondžić 2017; Koljanin 2015: 141-142; Čalić 2013: 135-136.

Dimić 1997: 205-213; See also: Gašić 2005.

AJ, 66-129-411, The Ministry of Education of the Kingdom of SCS, General Office - to the Ministry Council, 5 May 1924.

Gašić 2005: 188.

13 A large number of Yugoslav students were receiving their education in Czechoslovakia even before the formation of the Kingdom of SCS. The Czechoslovak government aimed at keeping up the tradition of cooperation with Yugoslavia in this area even after World War II. Petranović 1988b: 972. 
money every year to underprivileged students in Czechoslovakia. Furthermore, two permanent scholarship positions were established for Yugoslav students in Prague studying the Czech language, national history and any other sciences dedicated to the preservation of the Czechoslovak culture. In light of this, it was suggested that, as a means of cultivating closer ties between the Yugoslav and the Czech peoples, the Yugoslav Ministry of Education "established two such positions for Czechoslovak students who would, at Yugoslav universities, study the philological-historical, geographical-ethnographic or any other group of sciences which delve deeper into the understanding of Yugoslav peoples". ${ }^{14}$

The Ministry of Education of the Kingdom of SCS at the session on 5 May 1924 put forth a proposal that, as a symbol of gratitude to the French government for facilitating the schooling of the students from the Kingdom, at least two scholarships should be set up for French students who would, at Yugoslav universities, study scientific areas which were a part of, according to the terminology at the time, "the national science". The Ministry Council at the session on 8 May 1924 accepted the proposal to establish two scholarship positions for French and Czechoslovak students and authorized the Ministry of Education to hold a competition. ${ }^{15}$ This decision was later altered by increasing the number of scholarships for French students to three. ${ }^{16}$ Since there was also a large number of Yugoslav students studying at the Polish universities in Warsaw, Krakow and Lviv, in 1926 the Ministry Council acting on the proposal of the Ministry of Education decided to establish two permanent scholarships for Polish students expressing the desire to study the Serbo-Croatian language with literature, national history, Slavic studies or ethnography. Shortly after, the competition was held and the students chosen, so that in the school year 1926/1927 two Polish scholarship holders were studying at the Faculty of Philosophy, University of Belgrade. ${ }^{17}$

By the end of the 1920s the competition procedure and the selection criteria were gradually outlined in their final form. The competitions for foreign student scholarships were opened by the Ministry of Education of the Kingdom of SCS, based on the approval of the Ministry Council, every spring for the following school year. The Ministry of Foreign Affairs announced the competitions to the Royal Embassies in London, Paris, Prague and Warsaw. In most cases, these were one-year scholarships for the studies at the Faculty of Philosophy, at the departments of language, literature, history, geography, ethnography, i.e. for studying those scientific disciplines by means of which one would acquire an extensive understanding of the Yugoslav culture.

In order to meet the criteria of the competition, the applicants either had to have a BA degree or to be in the fourth year of their studies at the Faculty of Philosophy and to have a good knowledge of Serbo-Croatian or Slovenian. Along with the proof of their language level, they were supposed to enclose a description of their current curricula and a list of the courses they were planning to attend at the University in Belgrade. The

14 AJ, 66-129-411, The Ministry of Education of the Kingdom of SCS, General Office - to the Ministry Council, 5 May 1924.

15 Ibid. the Session of the Ministry Council, 8 May 1924.

16 AJ, 66-129-411, The Ministry of Education of the Kingdom of SCS, General Office - to the Ministry Council, 23 September 1926.

17 Bondžić 2017: 101; AJ, 66-129-411, The Ministry of Education of the Kingdom of SCS, General Office - to the Ministry of Foreign Affairs, Belgrade, 23 September 1926. 
scholarship holders had the obligation of writing a report of their activities at the end of each semester in two copies, one of which they would submit to the Yugoslav and the other to their country's Ministry of Education. The selection of the applicants was entrusted to the committee which included representative of the Royal Embassy on the one side and the Ministry of Education and the foreign universities students of which applied for the scholarship on the other. ${ }^{18}$ The decision on the scholarships was confirmed by the Minister of Education of the Kingdom of SCS. According to the terms of the competition, the scholarships holders were supposed to spend the winter semester at the University of Belgrade, with the possibility of attending the classes in the summer semester in Zagreb or Ljubljana. Thus, they would be eligible to enroll at the Faculty of Philosophy as full-time students of the study groups of their choice. The Ministry of Finance paid each scholarship holder between 2000 and 2500 dinars per month from the state budget, whereas the Ministry of Transport provided discounts on the railway tickets. Special care of the foreign students, their accommodation, language classes and their inclusion in the social life was given the educational representatives of the Royal Embassies. ${ }^{19}$ The number of the scholarships was determined mid 1920s. From the total of eight scholarships, three were awarded each year to French students, two to Czech and Polish students each and one to a British student. ${ }^{20}$

Despite everything previously stated, there still were no conditions for a thought-out, planned funding of foreign students. ${ }^{21}$ Scientific and educational workers and workers in the area of culture understood the importance of this form of cooperation and made attempts to develop and advance it. This is implied by the contents of the programmes of the state cultural policy during the second half of the 1920s. In that sense, the establishment of the French Institute at the Belgrade University in late 1926 was highly significant. The institutes were the centres of propaganda efforts, working systematically of the spread of foreign languages and cultures with the aim of sparking interest among the wider public. In addition, they were meant to occupy the position of intermediaries during all kinds of cultural exchanges. ${ }^{22}$ The so-called "Paris section" according to its statute was meant to establish the connections between French and Yugoslav universities, make contact with French scientists and student associations and take care of the French students in the Kingdom. However, the Institute was not an institution of French culture; rather, it would become one in 1937. Since this was an

18 In France the committe was composed of: Aleksandar Arnautović, representative of the Royal Embassy in Paris, Antoine Meillet, a famous linguist, the professor of comparative linguistics, the president of the Institute for Slavonic Studies in Paris and the author of the Serbo-Croatian Grammar, and André Vaillant, the professor of the Serbo-Croatian language in the School for Living Oriental Languages in Paris, also the author of a grammar book. AJ, 66-129-411.

19 They included prominent figures from the Yugoslav scientific, cultural and public life, who stayed in this position for many years: Dragutin Prohaska in Prague, Julije Benešić in Warsaw, Aleksandar Arnautović in Paris and Dragutin Subotić in London. Dimić 1997: 232; Bondžić 2017: 103-104; Sretenović 2008: 421-424; Gašić 2005: 142.

20 AJ, 66-129-411.

21 The policy of awarding scholarships to foreign students by the state authorities was shaped and formulated only after World War II. See also: Bondžić 2011: 223-224.

22 Before the Institute was opened, the work on exposing the Yugoslav society to foreign cultural influences took place in the societies and the clubs of friends (of France, Greast Britain, Poland, Czechoslovakia). Dimić 1997: 186-213, 229-244; Bondžić 2017: 103. 
institution created as a result of a private initiative, primarily by teachers of the French language, at that time it could not further contribute to the development of cooperation. ${ }^{23}$

In 1926 a decision was made to establish the Inter-Parliamentary Committee which would improve the economic and cultural relations with Czechoslovakia. Next year, in 1927, the Programme of the cultural community of Czechoslovakia and Yugoslavia was adopted, which was a document which determined the basic directions of the cultural cooperation of the two countries. This document also paid particular attention to the scientific and educational cooperation. As one of the measures for the improvement of cultural relations, the exchange of scholarships was put into the forefront, especially for the students of philology, history and ethnography. These programmes were largely not completed. ${ }^{24}$ Among other factors, the educational-legal documents such as the Resolution of the Committee for the Creation of the State Educational Programme from 1928 almost exclusively focused on the organization and the matters of educational instruction, whereas the exchange of students was not mentioned. ${ }^{25}$ The only significant improvement in that respect was made with the signing of the School Convention between the Kingdom of Serbs, Croats and Slovenes and the Republic of France on 14 April 1928. ${ }^{26}$

\section{The spread of the international cooperation of universities during the 1930 s}

During the 1930s foreign student exchange continued in line with the established practices, but with a noticeable tendency towards intensifying it and establishing a better organizational basis for its implementation over the following period. This development was crucially influenced by the conclusion of a series of agreements on the cultural cooperation in late 1920s and early 1930s. In addition to the School Convention with France from 1928, another important agreement was the Declaration of School and Cultural Ties with Czechoslovakia in $1929^{27}$ and the Agreement on Scientific, School and Art Relations with Poland in $1931 .^{28}$ In this way, the political alliances created previously were supposed to be given a new content matter and application, first and foremost in the area of intellectual cooperation. ${ }^{29}$ Considering that the contracts were based on the consent of the parties that signed that they would maintain, encourage and strengthen various forms of scientific,

\footnotetext{
Dimić 1997: 194-197.

Ibid. 232-235.

Educational Review, II, 1928, 163.

Archive of Yugoslavia, Belgrade, the Ministry of Education of the Kingdom of Yugoslavia, Confidential Archive, 66 pov., 72-190. (AJ, 66 pov.).

27 The Declaration of school and cultural ties between the Kingdom of Yugoslavia and the Czechoslovak Republic, AJ, 66 pov, 71-186; The Educational Review, 4 (1930), 381-382; Československo-jugoslavenska revue, 1 (1930), 4-5; Dimić 1997: 236.

28 The Law on the Agreement on Scientific, School and Art Relations between the Kingdom of Yugoslavia and the Republic of Poland, AJ, 66 pov, 72-192. The Official Gazette of the Kingdom of Yugoslavia, 14 January 1933, 17-21; Bondžić 2017: 105.

29 The Agreement on the Alliance between the Kingdom of SCS and Czechoslovakia from 1922 and the Pact of Friendship and Cordial Cooperation between the Kingdom of SCS and Poland from 1926. Jovanović 1939: 348, 531, 533.
} 
educational and cultural cooperation by any means at their disposal, the general belief was that they would significantly contribute to their mutual familiarization and fraternization. The many measures that were, thus, proposed - the cooperation of scientific and educational institutions, more frequent contacts between writers and artists, the translation of literary works, the exchange of expert and scientific publications, internships, excursions - also included the establishment of closer ties at all levels of the system of education, the creation of the conditions for a steady schooling of students abroad and, finally, the incentives for student exchanges. ${ }^{30}$ This, essentially, confirmed the principle of reciprocity, which had already been set as a goal during foreign student exchanges. Even though the number of Yugoslav students studying abroad far exceeded the number of foreign students studying at the universities in the Kingdom, ${ }^{31}$ the Ministry of Education, by means of these mutual scholarships, tried to maintain traditional ties with the universities in France, Czechoslovakia and Poland. This remained its goal throughout the period between the two World Wars, regardless of the major changes and the shift in foreign policy which would take place in mid 1930s.

After the assassination of King Aleksandar in Marseille in 1934 and the appointment of Milan Stojadinović to the position of the president of the Government in 1935, political events redirected the state interests of the Kingdom of Yugoslavia. Over the next period what took place was a gradual dissociation from France. The alliance of the Little Entente (Yugoslavia, Czechoslovakia and Romania) and the Balkan Pact (Yugoslavia, Greece, Romania and Turkey), although still in effect, gradually lost its significance in the changing international context. There was a strengthening of economic and political ties with Germany, the establishment of close relations with Italy, with which Yugoslavia entered into a pact of friendship in 1937. Meanwhile, British diplomacy strived to strengthen its position, using the backing of Milan Stojadinović, Prince Pavle's first appointee, as its exponent. ${ }^{32}$ In accordance with the shift in the course of foreign affairs new cultural ties needed to be affirmed, primarily with Germany and Great Britain, as they suppressed the French influence that had been dominant until that point. The greatest improvement was made in the relations with Germany, chiefly in the field of economic cooperation. Since the economic factor was crucial, German influence far outweighed the British one until the end of the analyzed period. ${ }^{33}$

30 AJ, 66 pov, 71-186; The Educational Review, 4 (1930), 381-382; AJ, 66 pov, 72-192; The Official Gazette of the Kingdom of Yugoslavia, 14 January 1933, 17-21; Bondžić 2017: 104-105; Dimić 1997: 236; Something, truly important, in the meaning of the Declaration from 13 November 1929 (23 January 1930), Československo-jugoslavenska revue, 2, 1932, 50-51.

31 According to the statistics of the Yugoslav Ministry of Education, in 1924 there were 80 students studying in France who were the recipients of the scholarships given by the French Ministry of Education and 16 who were received scholarships funded by the Foreign Affairs Ministry. At the same time, a British fund enabled the schooling of 11 Yugoslav students, whereas in Czechoslovakia, according to a confidential report of Dragutin Prohaska, the educational inspector of the Royal Embassy in Prague, around 100 Yugoslav students were enrolled. According to the statistics from 1940, there were 100 students in France, 18 in Great Britain, 50 in Germany, 40 in Italy and 2 Yugoslav students in Turkey. AJ, 66-129-411; 66-131-411; 66 pov, 77-144. Also see: Gašić 2005.

32 Selected literature: Čalić 2013: 161-162; Jovanović 1938; Id. 1939; Krizman 1975; Id. 1964; Vinaver 1985; Dimitrijević, Sretenović 2008; Petranović 1988a; Milak 1987

33 Gašić 2005: 20, 189, 199. 
A change in the orientation of foreign affairs was not immediately reflected in the scholarships allocated for foreign students. The reason for this was a decrease in the amount of funding for the exchange of students in the state budget, which resulted in the stagnation of the international university cooperation during the 1930s. ${ }^{34}$ Namely, in the school year $1934 / 1935$ only five scholarships were offered to foreign students, two of which were reserved for Czechoslovak students, and one for British, French and Polish students each. ${ }^{35}$ The situation remained the same in the following year. The number of offered scholarships was repeated in the school year 1936/1937. ${ }^{36}$ A change in the number of students and their structure with respect to the countries took place after the establishmend of the Committee for the Exchange of Foreign Students at the Ministry of Education in 1937.

A greater interest in foreign student exchange can be observed in the second half of the 1930s. Government institutions and private societies frequently addressed the ministries that had jurisdiction with requests to approve exchanges and the allocation of the necessary aid. There were opportunities for further development of the international university cooperation in the coming period. Besides Poland, there was an interest in the exchange with the universities in Romania, Bulgaria, Czechoslovakia, France, Germany, Italy, Greece and Turkey. This would certainly necessitate a more systematic exchange of students that would be better controlled and took place according to a predetermined plan. Up until then, the decisions on student applications for foreign exchange and the organization of excursions in the Kingdom were made by the Inter-Faculty board for the exchange of students at the University of Belgrade. ${ }^{37}$ The board made contact with the universities of the aforementioned countries regarding the petition to send their students for a summer internship. Most of the countries at that time were willing to receive Yugoslav students and to provide the material means for their scholarships, but only on the basis of reciprocity. The Ministry of Education, having realized that the goal of any student exchange was not only professional development, but also getting to know allied countries and friendly nations, addressed the Ministry of Foreign Affairs regarding this issue at the beginning of June $1937 .^{38}$

34 During the years of the dictatorship a decrease in the funding reserved for the maintenance of cultural ties with the international community can be noticed. The funding was decreased from 400,000 dinars in the school year 1931/1932 to 300,000 in 1932/1933 and to 180,000 in 1933/1934. The Budget of the Expenditures of the Ministry of Education in the Kingdom of Yugoslavia, 1931-1933.

35 AJ, 66-130-411, 1934.

36 Ibid. the Ministry of Education, Pbr. 21.958, 4 June 1936.

37 The committee selected the applicants in competitions that were opened to the students of medicine, technical sciences and agriculture, but not the students at the faculties of Philosophy and Law or the Seminary and Veterinary Faculties. In the competitions they chose „older students, excellent students, possibly those who already had practical experience in their given field and were favourably characterized with respect to their demeanor". AJ, 66-129-410, Minutes from the first session of the Committee for the foreign exchange of students in the Ministry of Education, 3 July 1937.

38 AJ, 66-129-410, the Ministry of Education to the Ministry of Foreign Affairs, 9 June 1937; the University of Belgrade, the Committe for the exchange of students - to the president of the Ministerial Council and the Foreign Affairs Minister, 19 May, 1937. 


\begin{tabular}{|c|c|c|c|c|c|c|c|c|}
\hline $\begin{array}{l}\text { School } \\
\text { year }\end{array}$ & $\begin{array}{c}\text { Great } \\
\text { Britain }\end{array}$ & $\begin{array}{l}\text { Czecho- } \\
\text { slovakia }\end{array}$ & France & Poland & Germany & Italy & Turkey & $\begin{array}{c}\text { The } \\
\text { Netherlands }\end{array}$ \\
\hline $1923 / 24$ & 1 & 1 & & & & & & \\
\hline $1924 / 25$ & 1 & 2 & 2 & & & & & \\
\hline $1925 / 26$ & 1 & 2 & 3 & & & & & \\
\hline $1926 / 27$ & 1 & 2 & 3 & 2 & & & & \\
\hline $1927 / 28$ & 1 & 2 & 3 & 2 & & & & \\
\hline $1928 / 29$ & 1 & 2 & 3 & 2 & & & & \\
\hline $1929 / 30$ & 1 & 2 & 3 & 2 & & & & \\
\hline $1930 / 31$ & 1 & 3 & 3 & 2 & & & & \\
\hline $1931 / 32$ & 1 & 3 & 3 & 2 & & & & \\
\hline $1932 / 33$ & 1 & 3 & 3 & 2 & & & & \\
\hline $1933 / 34$ & 1 & 3 & 3 & 2 & & & & \\
\hline $1934 / 35$ & 1 & 2 & 1 & 1 & & & & \\
\hline $1935 / 36^{39}$ & 1 & 2 & & 1 & & & & \\
\hline $1936 / 37$ & 1 & 2 & 3 & 2 & & & & \\
\hline $1937 / 38$ & 2 & 4 & 3 & 2 & & & & \\
\hline $1938 / 39$ & 2 & 5 & 3 & 2 & & & 2 & \\
\hline $1939 / 40$ & 2 & 5 & 3 & 2 & 2 & 2 & 2 & 1 \\
\hline $1940 / 41$ & 2 & & 3 & & 3 & 2 & 2 & \\
\hline
\end{tabular}

Table 1. The number of scholarships awarded to foreign students by the Ministry of Education of the Kingdom of SCS/Yugoslavia ${ }^{40}$

That same year it was decided that a committee for the foreign exchange of students was to be established within the Ministry of Education, comprised of two representatives of the Ministry of Education and two representatives of the Inter-Faculty board for the exchange of students at the University of Belgrade, one representative of the Ministry of Foreign Affairs and one representative of the Ministry of Transport. ${ }^{41}$ The Committee was

39 The data for school year $1935 / 1936$ are incomplete.

40 AJ 66-129-411; 66-130-411; 66-131-411.

41 AJ, 66-129-410, the Ministry of Education, Decision no. 22183, 17 June 1937. First such committe included: Đorđe Mijović, professor at the Faculty of Technical Sciences and Stanoje Nedeljković, professor at the Faculty of Agriculture and Forestry as the representatives of the Inter-Faculty board for student exchange at the university; Dušan Jakšić, head of the General Department at the Ministry of Education and Vladimir Janković, senior consultant at the Ministry of Education; Božidar Kovačević, consultant at the Ministry of Foreign affairs and Valter Stevan, senior consultant at the Ministry of Transport. AJ, 66-129-410, The University of Belgrade - to the Minister of Education, 17 June 1937; the Ministry of Transport - to the Minister 
tasked with proposing and undertaking necessary measures for the implementation of the student exchange, with handling the distribution of aid to the scholarship holders and with conducting any other tasks for which it was assigned jurisdiction by the Ministry of Education. ${ }^{42}$ The activities of the Committee soon produced results. In the school year $1939 / 1940$ not only was the number of scholarships increased, but in addition to the previous funding of French, British, Polish and Czechoslovak students, in accordance with the establishment of new international ties, the students from Germany, Italy and Turkey also became scholarship recipients. ${ }^{43}$ Evidence of plans for further development of student exchange can be seen in the statistics from 1940, which indicated that as many as $48 \%$ of the entire budget for the cultural cooperation was allocated for the foreign student scholarships. Not a single scholarship for the education of Yugoslav students at the universities abroad was distributed from this fund. ${ }^{44}$

However, within the altered international circumstances which resulted from the beginning of World War II in Europe, the awarded scholarships remained unused. The cooperation with Czechoslovakia and Poland started to decline by the beginning of 1939. After the signing of the Munich Agreement and the Annexation of the Sudetenland by the Nazi Germany in March 1939, the diplomatic relations between the Kingdom of Yugoslavia and Czechoslovakia broke down, which, by extension, also marked the cessation of cooperation in the fields of culture, science and education. In the summer of 1939, the Ministry of Education opened the competitions, the scholarship holders were selected, but all of them abandoned their plans of coming to Yugoslavia. The attack of Germany on Poland marked the beginning of World War II, with the Yugoslav government declaring its neutrality. The Polish students that found themselves in Yugoslavia were, in fact, refugees, on their way to other allied countries. At the proposal of the University of Belgrade, the Ministry of Finance made the decision to allow them to enroll in the winter semester without the necessary documentation or the tuition. ${ }^{45}$ For the school year 1940/1941 the competition for the enrollment of foreign students at Yugoslav universities was once again opened. From the total of 12 scholarships, two were supposed to be awarded to British students, three to French and Italian students each and two to Turkish students. No scholarships were allocated for the students from Czechoslovakia and Poland, whereas three scholarships set up for German students with the explanation that "they should be equal to French, given the neutrality of Yugoslavia". ${ }^{46}$

The work of the Committee for foreign student exchange and with it the development of the international university cooperation and the exchange of students were cut short by World War II. The activities that began between the two World Wars would continue after

\footnotetext{
of Education, 26 June 1937; the Ministry of Education, General Division, Decision no. 22183, 16 June 1937.

43 The diplomatic relations between the Kingdom of SCS and Turkey were established in 1925 with the signing of the Contract of Peace and Friendship. In the 1930s the Yugoslav-Turkish international cooperation was intensified with the signing of trade agreements. The Cultural Convention between the Kingdom of Yugoslavia and the Republic of Turkey was signed in 1938. Župančić, 13, 20-21; Jovanović 1939: 468-469, 532.

44 From the total of 600,000 dinars, 290,000 were supposed to be spent on the funding of foreign students. AJ, 66-131-411, 1940; the Budget of the expenditures of the Ministry of Education, KY, 1939.

45 Bondžić 2017: 112.

46 AJ, 66-131, Ministry of Education, Decision Nr. 18897, 1 July 1940.
} 42 Ibid. 
the liberation of Yugoslavia and the restoration of the University of Belgrade in brand new politico-ideological and social circumstances. The policy of funding foreign students would be formulated only at the end of the $1950 \mathrm{~s}$ and the beginning of the $1960 \mathrm{~s} .{ }^{47}$

\section{Historical topics in the studies and researches of foreign scholarship holders}

In the period between the two World Wars foreign students came to the Kingdom of Yugoslavia for the purpose of professional development, research for their doctoral dissertation, in order to build literature to publish books. They mostly used scholarships to improve their knowledge of Serbo-Croatian-Slovenian, of literature, history, geography, ethnography, those sciences which would allow them to become better acquainted with the culture of the people of Yugoslavia. Overall, most of the scholarship holders were philologists and slavists. Among them, many chose historical studies, whether as full-time or specialist studies. A pursuit of history in the given context was meant to facilitate a fulfillment of not only cultural, but also political and propaganda goals.

An interest of British students in the history of the Serbian people had already existed. The cooperation of the Serbian Government and the British academic circles during World War I continued into the period between the two World Wars. Through shared efforts a course of the Serbo-Croatian language was established and, later on, the School of Slavonic and East European Studies at King's College in London. Scientific contacts between Great Britain and Serbian, and later on, Yugoslav scientists were initiated by Robert Seton-Watson, a historian and university professor. As part of this cooperation, Stanoje Stanojević held a series of lectures at the University of London in the school year 1917/1918. ${ }^{48}$ In view of this tradition, the largest number of British students would choose the study of history. Among the first ones, already in 1923, there is a mention of Ms. Nicholson, a high-school teacher from England who studied the Serbian Language and Literature and wrote her doctoral dissertation about the Bogomils and the history of Bosnia until its fall. ${ }^{49}$ Based on the recommendation of the School of Slavonic and East European Studies in London, starting with 1926, another holder of the scholarship was E. F. Robinson, who, shortly prior to her arrival in Belgrade, at her home faculty defended her master's thesis on the topic of the Diplomatic relations between Serbia and England from 1862 to 1868 . Her biography states that she worked as a history teacher in an all-girls high school, whereas during World War I she worked in the service of the Serbian army in Thessaloniki as a head of the ambulance column, where she learned Serbian well. She intended to remain in Yugoslavia after her two-year studies, should the Ministry of Education hire her to teach the English language. ${ }^{50}$ In 1926 a scholarship was

47 Also see: Bondžić 2011: 231-302.

48 He held the following lectures: The Civilization of the Serbian people, The history of the Serbo Croatian race up to the $19^{\text {th }}$ Century, History of the Serbian in the $19^{\text {th }}$ Century. Ostojić-Fejić 1989: 146-147

49 AJ, 66-129-411, the Embassy of the Kingdom of SCS in London - to the Ministry of Education, General Department, 10 July 1923; Gašić 2005: 188.

50 AJ, 66-129-411, the Embassy of the Kingdom of SCS in London - to the Ministry of Education, General Department, 13 November 1925. 
awarded to Fanny Foster who studied classical languages and history in Belgrade. ${ }^{51}$ In the school year 1926/1927 and 1927/1928 a scholarship was awarded to Walter Angus Morison, who later became a professor of comparative Slavic studies at the School of Slavonic and East European Studies in London. Upon his arrival in Belgrade in 1926 he enrolled the Faculty of Philosophy where he studied at the department of Serbian Language and History. His decision was motivated by his work on the book of translations of Serbian epic poems from the period of the First Serbian Uprising, which was encouraged by R. Seton-Watson. In order to be able to provide a brief overview of the historical events in the introduction, Morison thoroughly studied the relevant literature and periodicals in Yugoslav libraries. ${ }^{52}$ The book Uprising of 1804 in Serbian Epic Poems was first published in 1942. ${ }^{53}$ This was one of the first translations of Serbian epic poems into English, also representing an important historical source for the study of the cultural history of the Balkans. The translation of poems was previously published periodically in the journal The Slavonic Review ${ }^{54}$ In the school year 1935/1936 Hubert Butler, a student of classical and modern languages (French, German and Russian) at the University of Oxford became a recipient of the scholarship awarded by the Yugoslav government. ${ }^{55}$ Before coming to the University of Belgrade, Butler travelled across the entire Yugoslavia as a correspondent of The Irish Times, spending some time in Zagreb through the Society of the friends of Great Britain, where he worked as an English teacher. ${ }^{56}$ He used his two-year studies to research the "arrival of Slavs to Southern Europe" at the Faculty of Philosophy in Belgrade. ${ }^{57}$ Among the English students in 1938 there are further mentions of Reginald George Arthur de Brey and his wife Elsie Victoria Westerby, who were at that time in their second year of linguistic studies and were attending the history lectures given by professor Dragoslav Stranjaković. ${ }^{58}$ In 1939 the de Breys went back to England where they were employed by the military department of censorship during the war. ${ }^{59}$

$51 \quad$ Ibid. 1926.

$52 \mathrm{Ibid}$. to the Ministry of Education in Belgrade, the Department of Higher Education, the Report on the work of the state scholarship holder W. A. Morison during the winter semester 1926/1927 at the Faculty of Philosophy in Belgrade, 7 March 1927, the Report on the work of the state scholarship holder W. Morison, 2 November 1927.

53 Morison 1942. The second edition was published in 2011.

54 The Slavonic and East European Review, 7 (19), 179-187, 187-188, 188-190; 8 (23), 389-399; 8 (24), 678-690.

55 Hubert Butler was a famous Irish essayist, journalist, historian. In the 1920s and 1930s he travelled across Eastern Europe and the Balkans. He is considered to have left, along with Rebecca West, one of the most significant travel essays about Yugoslavia between World Wars. He is remembered for helping to save Jews from Nazis in Austria after the Anschluss in 1938. Recently his work The Balkan Essays regained popularity. Đokić 2017: 207-210; See also: Butler 2016.

56 Before Zagreb, he worked as an English teacher in Egypt and Austria.

57 AJ, 66-131-411, the Educational representative of the Royal Embassy in London - to the Ministry of Education, Belgrade, 15 June 1935; Hubert Butler's application for the scholarship of the Ministry of Education, 12 July 1935; Copies of Testimonials from the President of St. John's College and Mr. Lennox, Robinson, March 1925; a Report - the selection of the scholarship holder Hubert Butler, English, 5 July 1935.

58 Gašić 2005: 189; AJ, 66-131-411, the Royal British Consulate, Belgrade - to the Ministry of Education of the KY, a Report on the studies in the school year 1937/1938 of the scholarship holders (1) Reginald George de Brey and (2) Elsie Victoria Westerby - de Brey, 23 June 1938. 
Unlike British students who, for the most part, used their scholarships for the duration of two school years, the French applicants showed greater interest in shorter study stays with the aim of improving their language and conducting research in the fields of literature and history. Most often, this was the case when there were fewer applicants applying for the scholarship. In that case, at the proposal of the educational representative of the Royal embassy in Paris, instead of one-year scholarships, a number of scholarships intended for a study stay of several months were awarded to students who, within their doctoral theses, analyzed the topics from the literature and history of Yugoslav peoples. Thus, during the summer months in 1926, the following students conducted research in Belgrade: Ives Chategneau, a former language instructor at the University of Belgrade, who was at the time employed at the Foreign Affairs Ministry in Paris; Andre Vaillant, a professor of the Serbo-Croatian language in the School for Living the Oriental Languages in Paris and Miss Privat, a high-school teacher, who analyzed the "development of political parties in Yugoslavia" for her doctoral dissertation she was to defend at the University of Paris. ${ }^{60}$

One of the two candidates proposed to be the scholarship holders in the school year 1927/1928 by the French Ministry of Foreign Affairs included Simone Belègue Missirlitch, a law student. ${ }^{61}$ She was enrolled at the Department of the Serbo-Croatian language, literature and history at the Faculty of Philosophy in Belgrade, focusing on the study of the diplomatic history of the Yugoslav peoples. She attended the courses taught by Stanoje Stanojević, Vladimir Ćorović, Slobodan Jovanović and Vasilj Popović. However, the majority of her time was devoted to the investigation of the literature for her doctoral thesis The Principality of Serbia and the Yugoslav National Movement in Hungary 1848/1849, which she was to defend at the Paris Law School at the University of Paris. ${ }^{62}$ In order to give her time to finish her research, the scholarship was extended to include the following school year of 1928/1929. ${ }^{63}$ The scientific results of her two-year stay in Belgrade were fruitful. In November 1928, in the organization of the Society of the friends of France, she held a lecture on the topic of French Diplomats with Serbs in $1848 .{ }^{64}$ Her lecture was published as an article in The Serbian Literary Herald. ${ }^{65}$ In 1929 she was chosen as a member of the Historical society in Novi Sad and regularly contributed to their journal. She wrote and published the article An important letter of Prince Aleksandar Karađorđević from 1849. ${ }^{66}$ She collaborated with the French newspaper Les Nouvelles Yugoslaves which was published in Belgrade. What is more, she actively worked on the Yugoslav propaganda in France. She contributed two articles to L'Écho de Paris, one of which focused on field marshal Stepa Stepanović, and the other on Macedonia (a study Among Serbs in Southern

60 AJ, 66-129-411, the Educational Department of the Embassy of KSCS in Paris - to the Ministry of Education, Belgrade, 5 June 1925; the Ministry of Education of the Kingdom of SCS, 15 June 1925.

61 AJ, 66-129-411, the Ministry of Foreign Affairs of the Kingdom of SCS - to the Ministry of Education, General Division, 18 August 1927.

62 The dissertation was in the field of international law and diplomatic history.

63 AJ, 66-129-411, the Ministry of Education, General Division, 4 October 1928.

64 Politika, 3 December 1928, 1.

65 The Serbian Literary Herald, 16 January 1929, 132-137; 7 February 1929, 201-208.

66 The Herald of the Novi Sad Historical Society, 2 (1929), 103-107. 
Serbia). She attended numerous conferences at the University, frequented receptions and banquets organized for visiting French scientists, aiming to "get to know Yugoslav art in all its forms". She dedicated her free time to attending concerts, theatre plays, art exhibits. In one of her reports she wrote that, having learnt about the "intellectual life" of Yugoslavia, she came to see it as her second homeland, which she grew "as fond of as of France" ${ }^{67}$

Yugoslav history and culture were also a point of interest of Louis Cordier, a college professor in Riom, a Salonica front veteran. In the school year 1927/1928 he held a series of lectures on the topic of Franco-Serbian collaboration during the Great War, as reported by the newspaper Politika. ${ }^{68} \mathrm{He}$ would continue to publish papers on this topic over the following three decades ${ }^{69}$ However, a far greater importance was that of the work on the Yugoslav propaganda done by the scholarship holders upon their return to their homeland. A notable example is that of Jean Bourgoin, a graduated philosopher and a general secretary of the French League of Patriots. ${ }^{70}$ Of note is his article in the newspaper Le Drapeau ${ }^{71}$ dated 10 July 1928, in which he tried to "prove by means of historical methods the culpability of Austria and Germany for World War I". ${ }^{72}$ Among the students from France who were at the University of Belgrade for their study stays during the 1920s it is also necessary to mention Madlenne Seris, a literature and history student, who wrote in her report from 1928 that she had been completely immersed in history by attending the lectures of Vladimir Ćorović and Stanoje Stanojević, ${ }^{73}$ and Gabrielle Sohier who in that same year studied the history of the Serbs in the Middle Ages. ${ }^{74}$

The largest number of Czechoslovak students included philologist and slavists, who later became prominent literary translators. At the 1925 competition opened for Czechoslovak students for the study at Yugoslav universities Viktor Hofhans, a student of philosophy, history and geography, was awarded the scholarship. ${ }^{75}$ While in Belgrade, he studied the history of the medieval Serbian and Croatian states, with particular interest in the Dalmatian towns under Byzantine, Venetian and Hungarian rules. He attended the lectures on the history of Croats held by Viktor Novak, researched and collected literature in the libraries in Belgrade and Zagreb. According to his own report, he took particular care in familiarizing himself with the Yugoslav historiography. ${ }^{76}$ Eduard Turek, a professor at

67 AJ, 66-129-411, The Ministry of Education of the Kingdom of SCS, General Division - to the Educational representative, Paris, 18 July, 1928.

$68 \mathrm{Ibid}$. the Educational department of the Royal Embassy in France - to the Ministry of Education, Belgrade, 15 February 1928; Politika, 1 December 1927, 5.

69 Pavlović 1996: 113.

70 AJ, 66-129-411, the Educational Department of the Royal Embassy in France - to the Ministry of Education, Belgrade 16 March 1928.

71 A magazine of the French League of Patriots.

72 AJ, 66-129-411, 1928.

73 Ibid. The Ministry of Education, General Division - to the Educational representative, Paris, 18 July 1928.

74 Ibid. the Educational department of the Royal Embassy in France - to the Ministry of Education, General Division, 25 September 1928.

75 AJ, 66-129-411, The Embassy of the Republich of Czechoslovakia, Belgrade - to the Ministry of Education, 24 February 1925; The Ministry of Education of the Kingdom of SCS, General Division, 2 November 1925.

76 Ibid. The Embassy of the Republich of Czechoslovakia, Belgrade - to the Ministry of Education of the Kingdom of SCS, A Report by V. Hofhans, a student of the University of Belgrade, 30 December 1925. 
the State female school for teachers in Prague, at the time working on his thesis about Serbian folk poems in Czechoslovak literature, chose to attend the classes which would enable him to thoroughly become familiarized with the history of Serbs: Cultural History of Serbs given by professor Stanoje Stanojević and Serbs and Turks given by professor Dušan Popović. ${ }^{77}$ Dr. Julius Heidenreich, a Prague high-school teacher, focused his research in the school year 1929/1930 on the field of cultural and political history of the Serbian state. He spent the time between his studies at the University and research in libraries pursuing his interest in the overall public and cultural life in Yugoslavia, especially in Belgrade. He was awarded the fifth class of the Order of Saint Sava for his services in building ties between Yugoslavia and Czechoslovakia. ${ }^{78}$

Because of her committed work student Věra Vrzalová stood out among the Czechoslovak scholarship holders. At the Faculty of Philosophy in Belgrade she was enrolled in the school year 1930/1931 at the Department of National History and Literature and attended the following classes: History of Serbian Historiography and Cultural History of Serbs in the Middle Ages given by professor Stanoje Stanojević and History of Bosnia between the $12^{\text {th }}$ and the $18^{\text {th }}$ century given by professor Vladimir Ćorović. Since she was, at the time, writing a doctoral dissertation on the topic of The First Government of Prince Mihailo, she primarily analyzed $19^{\text {th }}$ century history. She studied historical materials at the State archives and the National Library and read the literature at the seminar library for national history at the Faculty of Philosophy in Belgrade. This provided her with a comprehensive view of Yugoslav literature and history and allowed her to compile valuable sources for her doctoral thesis, on which she would continue work once she concluded her research in the Vienna archives. She held a lecture at the Czechoslovak colony in Belgrade, whereas she published an article entitled The State and National Serbian Programme of Ilija Garašanin in the Slavonic Review. In the journal Yugoslav-Czechoslovak Review she published a historical supplement on Pecija's Revolt. ${ }^{79}$ She made contact with the editorial board of the journal Thought and promised to send, upon return to her country, articles and reports about the cultural and public life in Czechoslovakia on a monthly basis. ${ }^{80}$ Verra Vrzalová later on became a translator of Serbo-Croatian literature. ${ }^{81}$

77 Ibid. The Embassy of the Republich of Czechoslovakia, Belgrade - to the Ministry of Education of the Kingdom of SCS, A Report by Eduard Turek, a scholarship holder of the Government of the Kingdom of SCS about his studies at the Faculty of Philosophy at the Royal University of Belgrade in 1928, 5 January 1929.

78 Ibid. AJ, 66-130-411, The Embassy of the Republich of Czechoslovakia, Belgrade - to the Ministry of Education of the Kingdom of SCS, A Report by Dr. J. Heidenreich, a scholarship holder of the Government of the Kingdom of SCS for the period between 1 October 1928 and 31 December 1928 about his studies at the Royal University of Belgrade, 3 January 1929; A Report by Dr. J. Heidenreich, a scholarship holder of the Government of the Kingdom of SCS, 1 January 1930; A Report by Dr. J. Heidenreich, a scholarship holder of the Government of the Kingdom of Yugoslavia, about his studies in the period between 1 January and 31 march 1930 in Belgrade; A Report by Dr. J. Heidenreich, a scholarship holder of the Government of the Kingdom of Yugoslavia, about his studies in Belgrade, 15 July 1930.

79 Československo-jugoslavenska revue, 3, 1931, 140-141.

80 AJ, 66-130-411, Věra Vrzalová, a scholarship holder of the Ministry of Education, Regular report, 1 April 1931; 15 July 1931; 10 January 1932; 5 April 1932.

81 Some of her translations - The Adventures of Nikoletina Bursać by Branko Ćopić from 1958 and two novels The Return of Filip Latinović and On the Edge of Reason by Miroslav Krleža, second edition published in Prague in 2013 - are kept in the libraries of Matica Srpska and the Serbian Academy of Sciences and Arts. 
Some of highly interesting topics were analyzed by Petro Lintur, a philologist. Originally from the Zakarpattia Oblast, he studied historical philology at the Charles University in Prague. He was one of the delegates at the Assembly which decided on the annexation of the Zakarpattia Oblast to Ukraine, following which he had considerable influence over education and culture of this region. He made a significant contribution to Ukrainian folklore studies and folk literature. He published about a dozen collections of stories, which were translated into several languages. ${ }^{82}$ As a scholarship holder in the school year 1935/1936, Lintur studied Slavic literature and history, paying special attention to the lectures within the course Overview of the History of South Slavs given by professor Dragoslav Stranjaković. He was a member of the University library and the Slavic seminar library for literature, philology and history. During his study stay in Belgrade he visited Bačka, where he held several lectures about the Carpathian Rusyns: he spoke about religious, cultural and economic circumstances in Sub-Carpathian Rus in Stari Vrbas, whereas in the village of Kucura he held a lecture about the cultural ties between Yugoslav and Carpathian Rusyns. Furthermore, he wrote several articles about Yugoslav Rusyns, their economic, cultural and religious circumstances, which he submitted for publication in Czech journals. ${ }^{83}$

During the 1920s several prominent philologists and slavists from Poland also studied at the University of Belgrade. Michal Antonów, an assistant from Lviv, was a student at the Department of history and the history of Yugoslav literature during the school year 1927/1928, where he attended classes held by professors Stanoje Stanojević and Viktor Novak. He collected sources and read literature relevant to his study of the uskoks from Senj. For this reason he also spent a period of time in Zagreb. His narrower field of interest were Cossacks around the River Dnieper and their relationship towards Poland during the first half of the $17^{\text {th }}$ century. He believed that his interest in the issue of uskoks and their relationship towards the Ottomans in the $16^{\text {th }}$ and the $17^{\text {th }}$ centuries was, by reason of analogy, historically justified. He wanted to get to know many places in the Kingdom, especially paying attention to the state of libraries and archives, on which, as he claimed "the progress in historical sciences is dependent". ${ }^{84}$ Besides him, the scholarship was also awarded to Mieczyslav Malecki, who studied at the department of Yugoslav literature, developed his knowledge of Slovenian, and attended lectures in Cultural history of the Serbs in the Middle Ages and Overview of Serbian history given by professor Stanoje Stanojević. ${ }^{85}$ During the school years 1927/1928 and 1928/1929 Zigmund Okninski studied

82 Lintur 1994: 1.

83 JA, 66-131-411, the Embassy of the Republic of Czechoslovakia in Belgrade - to the Ministry of Education of the Kingdom of Yugoslavia, Belgrade, A Report on the work Petro Lintur - a holder of the scholarship awarded by the Ministry of Education in Belgrade, 29 February 1936; 7 July 1936.

84 Bondžić 2017: 101; AJ, 66-129-411, the Embassy of the Kingdom of SCS, Poland - to the Ministry of Foreign Affairs, the General Political Direction, 11 July 1927; A Report by the holder of the scholarship of the Kingdom of SCS Michal Antonów on his work between 26 February and 26 May 1927, 26 May 1927; A Report by the holder of the scholarship of the Kingdom of SCS Michal Antonów during his work between January and April 1928; A Report by the holder of the scholarship of the Kingdom of SCS Michal Antonów on his work between 25 April and 10 July 1928, 10 July 1928.

85 AJ, 66-129-411, A Report by the holder of the scholarship of the Kingdom of SCS Mieczyslav Malecki on his work between 15 January and 1 April 1927; A Report by the holder of the scholarship of the Kingdom of SCS Mieczyslav Malecki on his work between 1 April and 30 June 1927; A Report by the holder of the scholarship 
the Serbian medieval state and worked on his doctoral thesis on the topic of Stefan Dušan - Emperor of Serbs and Greeks. He initially collected data on Serbian-Byzantine relations in the $14^{\text {th }}$ century at the National Library in Belgrade and then in the summer semester travelled to Zagreb to attend the lectures by Ferdo Šišić and Grga Novak on the position of the Southern Slavs during the time of Emperor Dušan. ${ }^{86}$ In the 1930s, historian and Slavic writer Henryk Batowski, later a professor at the Jagiellonian University and a translator of The Mountain Wreath ${ }^{87}$ into Polish, studied at the University of Belgrade. ${ }^{88}$

According to the preserved data on foreign scholarship holders for the school year 1940/1941 Sabine Loterbach, a student of Slavic and Eastern European history, came to Belgrade, while a German student of history had to give up his scholarship because he was drafted into military service. ${ }^{89}$

\section{REFERENCES:}

Unpublished archival sources:

Archives of Yugoslavia

The Ministry of Education of the Kingdom of Yugoslavia (funds sign: 66)

The Ministry of Education of the Kingdom of Yugoslavia, Confidential Archives (funds sign: 66 pov.)

Periodicals:

Budget of the expenditure of the Ministry of Education of the Kingdom of SCS/Yugoslavia [Budžet rashoda Ministarstva prosvete Kraljevine SHS/Jugoslavije]

Československo-jugoslavenska revue

Herald of the Historical Society in Novi Sad [Glasnik Istorijskog društva u Novom Sadu]

Politika

Educational Review [Prosvetni glasnik]

Official Gazette of the Kingdom of Yugoslavia [Službene novine Kraljevine Jugoslavije]

Serbian Literary Herald [Srpski književni glasnik]

The Slavonic and East European Review

References:

Bondžić, D. Misao bez pasoša: međunarodna saradnja Beogradskog univerziteta 1945-1960, Beograd: Institut za savremenu istoriju, 2011. (Serbian Cyrillic)

Bondžić, D. „Prosvetna, naučna i kulturna saradnja Kraljevine SHS/Jugoslavije i Poljske između dva svetska rata“, u: M. Pavlović, A. Zaćmiński i Paweł Wawryszuk (ur.), Jugoslavija i Poljska u

of the Kingdom of SCS Mieczyslav Malecki on his work between 15 January and 15 April 1928; A Report by the holder of the scholarship of the Kingdom of SCS Dr. Mieczyslav Malecki on his work between 15 October and 15 January 1928; A Report by the holder of the scholarship of the Kingdom of SCS Mieczyslav Malecki on his work between 15 April and 30 June 1928; Bondžić 2017:101.

86 Ibid. to the Head of the Department of higher education with the Ministry of Education; A Report on the scientific work during the summer semester in the school year 1928/1929; Bondžić 2017:101.

87 The Mountain Wreath was written by Prince-Bishop and poet Petar II Petrović-Njegoš.

88 Ibid. 107; Bunjak 1999: 77, 86; Id. 2000.

89 AJ, 66-131-411, The Ministry of Education of the Kingdom of Yugoslavia, General Division - to the Ministry of Foreign Affairs, 10 October 1940. 
$X X$ veku, Beograd: Institut za savremenu istoriju; Bidgošć: Institut za istoriju i međunarodne odnose, 2017, 97-114.

Bunjak, P. Pregled poljsko-srpskih književnih veza: do II svetskog rata, Beograd: Slavističko društvo Srbije, 1999. (Serbian Cyrillic)

Bunjak, P. „Hronika Botovskog: poljski prevod Njegoševog Gorskog vijenca i njegovi kritičari“, Anali Filološkog fakulteta, 20, 2000, 241-271. (Serbian Cyrillic)

Butler, H. Balkanski eseji, Zaprešić: Fraktura, 2016.

Čalić, M. Ž. Istorija Jugoslavije u 20. veku, Beograd: Klio, 2013. (Serbian Cyrillic)

Dimitrijević, B. i Sretenović, S. „Spoljna politika Kraljevine SHS/Jugoslavije 1918-1941“, Istorija 20. veka, 2, 2008, 45-83. (Serbian Cyrillic)

Dimić, Lj. Kulturna politika u Kraljevini Jugoslaviji 1918-1941: politika i stvaralaštvo, Beograd: Stubovi kulture, 1997. (Serbian Cyrillic)

Đokić, D. 'Hubert Butler and Yugoslavia', Croatian Political Science Review, 4, 2017, 207-216.

Gašić, R. Beograd u hodu ka Evropi: kulturni uticaji Britanije i Nemačke na beogradsku elitu 1918-1941, Beograd: Institut za savremenu istoriju, 2005.

Grbić, B. Bibliografija o Beogradskom univerzitetu 1838-1987, Beograd: Univerzitet, Savremena administracija, 1988. (Serbian Cyrillic)

Janićijević, M. Stvaralačka inteligencija međuratne Jugoslavije, Beograd: Institut društvenih nauka, Centar za sociološka istraživanja, 1984.

Jovanović, J. Diplomatska istorija Nove Evrope 1918-1938, I, Beograd: Knjižara Koste J. Mihailović, 1938. (Serbian Cyrillic)

Jovanović, J. Diplomatska istorija Nove Evrope 1918-1938, II, Beograd: Knjižara Koste J. Mihailović, 1939. (Serbian Cyrillic)

Koljanin, M. „Poljske izbeglice u Jugoslaviji 1939-1941. godini“, u: M. Pavlović, A. Zaćmiński i D. Bondžić (ur.), Jugoslovensko-poljski odnosi u XX veku, Beograd: Institut za savremenu istoriju; Bidgošć: Institut za istoriju i međunarodne odnose, 2015, 141-154.

Krizman, B. „Italija u politici kralja Aleksandra i kneza Pavla (1918-1941)”, Časopis za suvremenu povijest, 1, 1975, 33-97.

Krizman, B. Vanjska politika Jugoslavenske države 1918-1941: diplomatsko-historiski pregled, Zagreb: Školska knjiga, 1975.

Lintur, P. A Survey of Ukrainian Folk Tales: translated and with an introduction by Bohdan Medwidski, Edmonton: Canadian Institute of Ukrainian Studies Press, 1994.

Marković, P. Beograd i Evropa 1918-1941: evropski uticaji na proces modernizacije Beograda, Beograd: Savremena administracija, 1992.

Marković, P. „Evropski uticaj na Beogradski univerzitet između dva rata“, u: M. Vasić, M. Mitrović i N. Božinović (ur.), Ideje i pokreti na Beogradskom univerzitetu od osnivanja do danas: saopštenja i prilozi sa Simpozijuma održanog u Beogradu 15-17. novembra 1988. godine, 1, Beograd: Centar za marksizam Univerziteta, 1989, 181-191. (Serbian Cyrillic)

Milak, E. Italija i Jugoslavija 1931-1937, Beograd: Institut za savremenu istoriju, 1987.

Morison, W. A. The Revolt of the Serbs against the Turks (1804-1813): translations from the Serbian national ballads of the period with an introduction, Cambridge: Cambridge University Press, 1942.

Morison, W. A. The Revolt of the Serbs against the Turks (1804-1813): translations from the Serbian national ballads of the period with an introduction, Cambridge: Cambridge University Press, $2011^{2}$.

Ostojić-Fejić, U. „Saradnja profesora Beogradskog univerziteta sa Srpskim potpornim fondom u Londonu na školovanju srpskih studenata tokom Prvog svetskog rata“, u: M. Vasić, M. Mitrović i N. Božinović (ur.), Ideje i pokreti na Beogradskom univerzitetu od osnivanja do danas: saopštenja i prilozi sa Simpozijuma održanog u Beogradu 15-17. novembra 1988. godine, 1, Beograd: Centar za marksizam Univerziteta, 1989, 143-148. (Serbian Cyrillic) 
Pavlović, M. U dvostrukom ogledalu: francusko-srpske kulturne i književne veze, Beograd: Prosveta, 1996. (Serbian Cyrillic)

Petranović, B. Istorija Jugoslavije 1918-1988: Kraljevina Jugoslavija 1914-1941, Beograd: Nolit 1988a. (Serbian Cyrillic)

Petranović, B. „Jugoslovenski studenti - stipendisti u inostranstvu i strani studenti na jugoslovenskim univerzitetima 1945-1948, u: A. Mitrović (ur.), Univerzitet u Beogradu 1838-1988, Beograd: Univerzitet, 1988b, 969-977. (Serbian Cyrillic)

Samardžić, R. „Nauka u Beogradu 1918-1941“, u: V. Čubrilović (ur.), Istorija Beograda, 3, 1974, 320-336. (Serbian Cyrillic)

Sretenović, S. Francuska i Kraljevina Srba, Hrvata i Slovenaca 1918-1929, Beograd: Institut za savremenu istoriju, 2008.

Sretenović, S. 'French cultural diplomacy in the kingdom of Serbs, Croats and Slovenes in the 1920s'. European Review of History, 1, 2009, 33-47.

Stanković, Đ. Studenti i Univerzitet 1914-1954: ogledi iz društvene istorije, Beograd: Centar za savremenu istoriju jugoistočne Evrope, 2000. (Serbian Cyrillic)

Tešić, V. „Školstvo u Beogradu 1918-1941“, u: V. Čubrilović (ur.), Istorija Beograda, 3, 1974, 307-319. (Serbian Cyrillic)

Vinaver, V. Jugoslavija i Francuska između dva svetska rata: da li je Jugoslavija bila francuski "satelit", Beograd: Institut za savremenu istoriju, 1985.

Župančić, T. „Poslanstvo Kraljevine Jugoslavije u Turskoj - Carigrad, Ankara 1919-1945. (1890-1945): istorijat stvaraoca i značaj arhivske građe fonda“, Arhiv, 2, 2004, 9-26. (Serbian Cyrillic) 


\section{ПАУЛИНА ЧОВИЋ}

Универзитет у Новом Саду, Филозофски факултет

Одсек за историју

\section{СТРАНИ СТУДЕНТИ НА БЕОГРАДСКОМ УНИВЕРЗИТЕТУ И ЊИХОВА ИНТЕРЕСОВАҢА ЗА ИСТОРИЈУ ЈУЖНОСЛОВЕНСКИХ НАРОДА}

(1923-1941)

\section{Резиме}

Почевши од средине двадесетих година прошлог века на Београдском универзитету омогућено је школовање и усавршавање страних студената, пре свега захваљујући стипендијама које је додељивало Министарство просвете Краљевине СХС/Југославије. Први конкурси расписани су за оне државе које су помагале школовање југословенских студената на својим универзитетима. Тако су у почетку на студије у Београд долазили француски, британски, чехословачки и пољски студенти. До краја двадесетих постепено је уобличена процедура расписивања и спровођења конкурса и критеријуми одабира студената, али још увек није постојало осмишљено и планско стипендирање странаца. Тридесетих година размена студената се настављала, видно интензивније и организованије, пре свега због потписивања културних споразума између Краљевине Југославије и влада појединих држава. Тиме је и фактички био потврђен принцип реципроцитета коме се одраније тежило приликом размене студената. У пракси је то било тешко оствариво и број стипендиста је варирао у зависности од расположивих средстава у државном буџету. Први видљиви резултати у међународној универзитетској размени остварени су после оснивања Комитета за размену студената са иностранством при Министарству просвете 1937. године. Не само да је у наредној школској години повећан број стипендија, него су поред ранијих француских, британских, чехословачких и пољских, а у складу са променом курса спољне политике, стипендирани и турски, немачки и италијански студенти. Стипендисти су најчешће усавршавали српско-хрватски или словеначки језик, изучавали књижевност и бавили се југословенском културом уопште. Међу њима, многи су се опредељивали за историју, било да је реч о редовним или специјалистичким студијама. Бављење историјском науком у датом контексту требало је да послужи остваривању не само културних, него и политичких и пропагандних циљева. Да су постојали планови за даљи развој размене студената, показују подаци из 1940. године када је од укупног буџета за културну сарадњу чак $48 \%$ било намењено за стипендирање страних студената. Међутим, у измењеним међународним околностима и услед отпочињања Другог светског рата у Југославији, није било могућности да се додељене стипендије реализују. Политика стипендирања страних студената биће формулисана тек крајем 50 -тих и почетком 60 -тих година XX века.

Кључне речи: Краљевина Срба, Хрвата и Словенаца/Југославија, Министарство просвете, културна политика, Београдски универзитет, стипендије, страни студенти, историја. 